\title{
BACTERIOLOGICAL ANALYSIS OF FRESH FISH (CAT FISH) SOLD IN OZORO MARKET
}

\author{
Orogu J.O.* and Okobia B. U.
}

Department of Science Laboratory Technology, Delta State Polytechnic Ozoro, Delta State, Nigeria

Email- joshuaorogu4@gmail.com

(Received on date: 09.05.2021

Date of Acceptance: 10.07.2021

Date of publication: 30.07 .2021 )

\begin{abstract}
The bacteriological analysis of fresh fish (Cat fish) sold in Ozoro market was carried out to evaluate the bacteriological quality of fresh fish and also provide some relevant information on the microflora of the species commonly found in fresh fish. 13 Samples were obtained from ozoro market and were labelled A to $M$. The samples were cultured and sub-cultured in appropriate media and the microorganisms were identified according to their morphological and biochemical characteristics. A total of four (4) bacterial isolates were obtained; Enterococcus spp, Streptococcus pyogen, Staphylococcus aureus, and Bacillus spp. The total heterotrophic count for bacteria ranged from $1.26 \times 10^{3} \mathrm{cfu} / \mathrm{ml}$ to $9.6 \times 10^{3} \mathrm{cfu} / \mathrm{ml}$. Bacillus spp. has the highest occurrence of $38.46 \%$ while Streptococcus pyogene has the least occurrence of $15.38 \%$. The result of the study shows that fresh catfish harbor a great measure of pathogenic microorganisms and this could be as a result of improper handling during harvesting. Regular draining of ponds after specific period will reduce or help eliminate the risk of fresh catfish borne disease.
\end{abstract}

\section{Keywords: Nil}




\section{INTRODUCTION}

Fish is a very vital source of high quality protein and constitutes an important parts of man's diet. It is the most important animal protein food available in the tropics, and it represents about $14 \%$ of all animal protein on a global basic (Abolagba and Melle, 2018; Tyo, 1997; 2001; Clucas and Ward, 1996). Spoilage soon sets in which is occasioned by an increase in the ambient temperature that triggers favourable conditions for microorganisms to thrive. Thus, the quality of fish as well as its potential keeping time deteriorates rapidly leading to food loss with regards to acceptable quality. This deterioration is due to growth of microorganisms or "non-microbial causes such as lipid oxidation (Martin, 1994). Essuman (1992) stated that Africa is endowed and constitute a rich source of numerous species of fresh fish. Such species include Clarias spp, Baqrus spp, Tilapia spp amongst others (Mabawo et al., 1982 and Motwani, 1970).

Fish has become increasingly important source of protein and other element necessary for the maintenance of healthy body (Adebayo et al., 2012). The African catfish, Clariasgarie pinus has been reared for about 20years in Africa with mixed success, the total farmed production of these species being only 3.978 metric tonnes or $7.46 \mathrm{mt}$ in Africa (Udeze et al., 2012). Clariasgarie pinusis highly nutritious fish that contains high amount of vitamins, proteins, minerals and little or no saturated fat and is low in carbohydrate (Udeze et al., 2012). Annual domestic fish supply in Nigeria stands at about 400,000 tonnes. The fishery sector accounts for about 2 percent of national GDP, 40 percent of animal protein intake and a substantial proportion of employment, especially in rural areas. The sector is a principal source of livelihood for over 3 million people (De Graaf et al., 1996). Nigeria is the largest African aquaculture producer, at 15,489 tonnes per year, Egypt (5,645 tonnes) follows Nigeria and then there are only five other countries (Zambia, Madagascar, Togo, Kenya and Sudan) that each produce more than 1000 tonnes (Hussein et al., 2002). Fish take a large number of bacteria into their gut from water sediment and food (Adedeji et al., 2011). It has been well known that both fresh water and brackish water fishes can harbor human pathogenic bacteria particularly the coliform group (Adedeji et al., 2011).

Fish meat deteriorates more quickly than other muscle foods, particularly when poorly handled. This spoilage is primarily bacterial in nature but other factors such as enzymatic breakdown of the tissues contribute to spoilage. About $30 \%$ of landed fish are lost through microbial activity alone (Ghaly et al., 2010; Huisint et al., 1996). Even with the improved food safety, progress is still uneven and food borne outbreaks from microbial contamination, chemicals and toxins are still common in many countries (WHO, 2007). Among all the food borne disease out breaks reported globally, seafoods accounts for up to $8 \%$ of all outbreaks (Huss, 2003). 
The microbial flora associated with fish is sometimes a reflection of their aqueous environment (Arafat, 2013). Water being a natural habitat for a wide range of microorganisms including bacterial, protozoa and fungi, fish taken in or harbour these organisms from its environment. These organisms may be pathogenic to fish as well pathogenic to humans when ingested. Bacteria such as Pseudomonas fluorescens, Aeromonas hydrophila, Edwardsiella tarda, Vibrio spp are ubiquitous in the aquatic environment (Gilmour et al., 1976, Allen et al., 1983). Pathogenic bacteria such as E. coli, Salmonella, Shigella are most times introduced into water bodies through human or animal feaces. When fishes from these environments are ingested they could pose a greak risk to the health of the consumers (Sumer et al., 2014).

\section{Materials and Methods}

\section{Study area}

This study was conducted in Ozoro with samples of fresh catfish in Ozoro, Delta State. The samples were collected from the market in the town. This town (Ozoro) is located in Delta State South-South Nigeria.

\section{Sample collection}

Thirteen samples of cat fish were obtained from ozoro market. Samples were collected in a sterile container and were taken under aseptic condition to the laboratory for microbiological analysis.

\section{Materials}

The materials used for this research work are; Electrical thermostatic incubator, Microscope, Weighing balance, Nutrient agar, Blood agar, Sabourous Detrose Agar(SDA), Conical Flasks, Distilled water, Measuring cylinders (50ml), Spatula, Masking tape, Petri dishes, Methylated spirit, Pressure pot Gas Cylinders, Methylene blue, Wire loop, Bunsen burner, Microscopic slide and Oil Immersion etc.

\section{Method}

\section{Isolation and enumeration of microorganisms.}

The solution containing the distilled water and pounded catfish was inoculated into each already prepared agar medium (Nutrient, Blood Agar and SDA respectively). The wire loop was used to streak each petri dish containing solidifies agar medium. The inoculated plate was incubated at 370 for 24hours. Distinct colonies were isolated and reinoculated unto appropriate agar medium (Nutrient Agar). The sub-cultured plate was incubated for another 24 hours at $40^{\circ}$ for the purpose of identification.

\section{Identification of isolates}

Gram staining: A colony from the purified subculture was isolated and emulsified in sterile distilled water and a thin preparation was made on the slide. It was evenly spread to covered an approximately are of about $15-20 \mathrm{~mm}$ in diameter on the slide. The smear made was left to dry being protected from dust and sunlight. The smear was fixed using gentle heat by rapidly passing the slide with the smear uppermost three (3) times through the flue 
of a Bunsen burner. The slide was checked with the back of the hand just to make sure too much heat was not used which can affect or even kill the microorganisms. The smear was allowed to cool before staining was done.

The microscopic slide containing the smear was placed on the staining rack and covered with crystal violet and allowed for 30-60 seconds. Wash off with distilled water slowly and gently. A drop of Lugol's iodine was added and allowed for 30-60 seconds as well; Then wash off slowly and gently with distill water.

The water was then tipped off. A drop of Acetone(Alcohol) was added off immediately again, a drop of Neutral red was added and allowed for 2 minutes then washed off with distilled water. The back of the slide was wiped clean and placed on a draining rock for the smear to air-dry, using microscope. The smear was examined with $40 x$ objective lens to check the staining pattern (checked without oil immersion). Oil immersion was added and viewed fewer than 100x Objectives lens to observe the shape, colour and other characteristics.

\section{Biochemical test}

a. Citrate utilization test: For each bacterial isolate $100 \mathrm{ml}$ of citrate medium was dispensed into each of the fore test tubes and sterilized by the use of gas cylinder and pressure pot for 30mins. The organism was then inoculated into citrate medium and incubated at $57 \circ \mathrm{C}$ for $24-48$ hours. A change in colour from green to blue indicated containing only the citrate medium sterried as a control (Chessbrough, 2005).

b. Catalase test: A drop of $3 \%$ hydrogen peroxide was placed on a glass slide. A bit of growth each isolate was collected from the medium using a wire loop and the growth has emulsified in the drop. A positive test was indicated by bubbling and frothing; negative test did not show bubbling fronthing (Cheesbrough, 2005).

c. Oxidase test: A piece of fitter paper was placed on a clean sterile petri dish and 3 drops of oxidized reagent was added. The bacterial isolated were sheared on the filter paper by means of sterilized rod. Organisms indicated positive when it retains the purple colouration with five to ten seconds of the analysis.

d. Indole test: Bacterial Isolates were inoculated into peptone water medium contained in sterilized test tubes then incubated at $370 \mathrm{C}$ for 24 hours to give optimum accumulation of indole. After the incubation period, about $0.5 \mathrm{ml}$ of Kovac's reagent was added $505 \mathrm{~m}$ of peptone water culture. The bottles were shaken thoroughly and allowed to stand and observed for colour development. A red colouration in the uppermost layer of the tube indicated a positive result. And if the isolate is negative, the reagent layer will remain yellow or slightly cloudy(Cheesbrough 2005).

e. Triple sugar iron agar test (TSI): Bacterial Isolated were stabbed into TSI slant media and also streaked on the surface of the slant after which the medium was of the slant after which
I Innovative Association 
incubated at optimal temperature of $37 \circ \mathrm{C}$ for 24 hous. The TSI slant medium was used to check for the presence of the following.

i. Gas: If bubbles is present in the media (gas positive)

ii. $\mathrm{H}_{2} \mathrm{~S}$ : If black is present in the media ( $\mathrm{H}_{2} \mathrm{O}$ Positive)

iii. Lactose: If the top of the media turns from pink to yellow (lactose positive).

f. Motility test: A single colony of each of the organism was inoculated into labeled test tube containing peptone water $(5 \mathrm{ml})$ and the tube incubated at $37{ }^{\circ} \mathrm{C}$ over-night.

A drop of the well-mixed organisms in peptone water incubated over-night was placed on a cover slip and the edges surrounded with oil immersion. A microscopic slide was then placed over the cover slip taking care that the slide does not touch the drop on the cover slip bur suspended by the oil immersion. The slide was then observed under the microscope for motile bacteria under X100 objective (Cheessbrough, 2005).

\section{Results and Discussion \\ Results}

The bacterial isolated from the catfish (Fresh) were Enterococus spp, Streptococcus pyogene, Staphylococcus aureus, and Bacillus spp. (Table 1).

Table 1 shows Cultural, Morphological and Biochemical characteristics and identification of bacterial isolates. Table 2 shows Total heterotrophic plate count. Table 3 shows Percentage of occurrence of bacterial isolates. Bacillus spp. has the highest occurrence while Streptococcus pyogene has the least occurrence.

Table 1: Cultural, Morphological and Biochemical characteristics and identification of bacterial isolates.

\begin{tabular}{|c|c|c|c|c|c|c|c|c|c|}
\hline $\begin{array}{l}\overline{0} \\
\sum_{0}^{\circ} \\
\stackrel{0}{2} \\
0\end{array}$ & $\stackrel{\Xi}{: \Xi}$ & $\frac{\ddot{\Xi}}{\tilde{\Xi}}$ & $\underset{\overparen{E}}{\stackrel{\Xi}{\Xi}}$ & $\frac{0}{\mathscr{J}}$ & 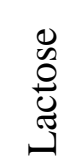 & $\stackrel{\mathcal{N}}{\mathcal{I}}$ & $\begin{array}{l}0 \\
\mathscr{0} \\
0 \\
0 \\
0\end{array}$ & $\frac{0}{0}$ & 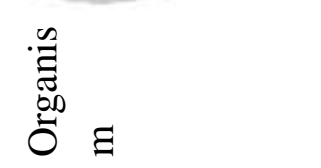 \\
\hline $\begin{array}{l}\text { Gram } \\
\text { +vecocci }\end{array}$ & + & - & + & + & + & + & - & + & Enterococcus spp \\
\hline $\begin{array}{l}\text { Gram } \\
\text { +vecocci }\end{array}$ & - & + & + & + & + & + & + & + & Streptococcus spp \\
\hline $\begin{array}{l}\text { Gram } \\
\text { +vecocci }\end{array}$ & + & - & + & - & + & + & + & + & $\begin{array}{l}\text { Staphylococcus } \\
\text { aureus }\end{array}$ \\
\hline $\begin{array}{l}\text { Gram } \\
\text { +vecocci }\end{array}$ & + & + & - & + & + & + & - & + & Bacillus spp \\
\hline
\end{tabular}


Table 2: Total heterotrophic plate count

\begin{tabular}{ll}
\hline Samples & Bacteria count \\
\hline $\mathrm{A}$ & $8.0 \times 10^{3}$ \\
$\mathrm{~B}$ & $9.0 \times 10^{3}$ \\
$\mathrm{C}$ & $5.0 \times 10^{3}$ \\
$\mathrm{D}$ & $9.4 \times 10^{3}$ \\
$\mathrm{E}$ & $7.5 \times 10^{3}$ \\
$\mathrm{~F}$ & $9.6 \times 10^{3}$ \\
$\mathrm{G}$ & $1.26 \times 10^{3}$ \\
$\mathrm{H}$ & $4.8 \times 10^{3}$ \\
$\mathrm{I}$ & $3.9 \times 10^{3}$ \\
$\mathrm{~J}$ & $1.37 \times 10^{3}$ \\
$\mathrm{~K}$ & $8.6 \times 10^{3}$ \\
$\mathrm{~L}$ & $9.0 \times 10^{3}$ \\
$\mathrm{M}$ & $7.9 \times 10^{3}$ \\
\hline
\end{tabular}

Table 3: Percentage of occurrence of bacterial isolates

\begin{tabular}{lll}
\hline Organisms & No. of occurrence & Percentage (\%) of occurrence \\
\hline Enterococcus spp & 3 & 23.08 \\
Streptococcus pyogene & 2 & 15.38 \\
Staphylococcus aureus & 3 & 23.08 \\
Bacillus spp & 5 & 38.48 \\
Total number of isolates & 13 & 100 \\
\hline
\end{tabular}

\section{Discussion}

Result of the gram staining, the cultural and morphological characteristics of isolates revealed that Enterococcus spp, Streptococcus pyogene, Staphylococcus aureus, and Bacillus spp were the bacteria species present in the samples assessed
(Table 1). The total heterotrophic count ranges from $1.26 \times 10^{3}-9.6 \times 10^{3}$ (table 2 ). Bacillus spp. has the highest occurrence of $38.46 \%$ while Streptococcus pyogene has the least occurrence of $15.38 \%$ (Table 3 ). The consumption of fresh African catfish (Clarius garierpinus) is on the increase in 
both rural and urban centers of Nigeria (Emikpe et al., 2011; Adedeji et al., 2012). Fish is an important food commodity in the international trade but deteriorates rapidly when storage facilities are lacking (Adedeji et al., 2012).

From the results of this study, it was discovered that bacterial loads of the catfish (fresh) showed a slight difference from other parts of the fish.

Based on the frequency of occurrence, Bacillus spp record the highest percentage of $38.46 \%$. The presence of these organisms might be associated with habitat in which it was caught. (Oraser and Hill, 1990, Shinkafi and Ukwaja, 2010, 2010). Bacillus spp is known to cause a number of infectious disease such $s$ septicemia, wound and food borne infections, meningitis, respiratory and urinary tract infections. (Morales et al., 2004; Shinkafi and Ukwaya, 2010; Bassey et al., 2015).

The detection of these pathogenic microorganisms in the catfish sample analyzed may be from the source in which it was harvested and the environment where the fishes are sold. Worthy of note in this study is the presence of both spoilage and pathogenic bacteria species that were isolated from the fish samples analyzed. The most prominent of these group of bacteria isolated include, Bacilluss spp, Enterococcus spp, Streptococcus pyogene and Staphylococcus aureus. These organisms are pathogenic and can be become harmful it consumed without proper processing. The pressure of these isolates from catfish could create health hazard when they are ingested or when they come in contact with the human skin. This exposed or people eating this catfish to the risk of food borne infection.

\section{Conclusion and Recommendations Conclusion}

Based on the result from the study, it can be concluded that the fresh catfish harbours a great percentage of bacteria. This study shows the prevalence of Bacillus spp. In cat fish. The quality of catfish is influenced by habitat, harvesting tools and handling (display) of this fish for buyers which eventually encourage cross contamination. It is therefore suggested that adequate measure should be taken while harvesting, preserving and processing the fish before consumption, cooking properly immediately before consumption is also an effective way of reducing or eliminating risk of fresh catfish borne disease.

\section{Recommendations}

The following should be taken into consideration to help stop or eliminate microbial contamination of fresh catfish use in homes, restaurants. It is recommended that;

i. the environment where fish ponds are located should be protected from pollutants and weeds which can harbour microorganisms that can find their way into fish ponds by themselves of by passive process though wind rainfall etc.

ii. The sanitary conditions under which fishes are reared or cultured should be improved by following standards or good practices such as good quality water, use of feeds with high microbial quality, regular draining of pond water after specific period of time and closure of ponds to the public.

iii. Fish handlers with open wounds should avoid contact with water from fish ponds 2021 July Edition | www.jbino.com | Innovative Association 
and fish should be properly cooked with heat before consumption.

iv. Workers should be educated on good hygienic practices

\section{REFERENCES}

Abolagba, O.J and Mele 0.0 (2008): Chemical composition and keeping qualities of a scaly fish Tilapia(Oreochromisniloticus) smoked with two energy sources. African J. Gen. Agrc., 4(2): 113-117

Adebayo-Tap, A.C., Odu., N.N.; Igwiloh, N.J.P.N and Okongo, I.O Microbial quality of frozen fish sold in Uyoh metropolis Nature and Science, 10(3), 2012, 71-77.

Adedeji, O.B.; Tiamiyu, A.M and Emikpe, B.O. Isolation and identification of Aerobic Bacterial Flora of the skin and stomach of wild and cultured clariasgariepinus and Oreochromis of Apllied sciences Research. 7(7), $2011,1047-1051$.

Arafat, M.G (2013). Microbial assessment of three types of fresh fish (Tilapia niloticus, Labeoniloticus and Hydrocynusspp).Sold in Ed Duein, Sudan. NY scieJ.6(4):49-54.

Degraaf, $\mathbf{G}$ and Jassen, J. Handbook on the artificial reproduction and pond rearing of the African catfish clariasgariepinus in subsaharan Africa (FAO) Fisheries Technical paper, 1996).

Delgado CL, Wada N, rosegrant MW, Meijer S, Ahmed $\mathbf{M}$ (2003) the fish issues and trends to 2020. International food policy Research institute, Whashington DC, USA.

Department of fisheries Malaysia(2010) Annual fishery statistic 2010. Department of Fisheries Malasia, Malasia.

Essuman, K.M(1992) Fermented Fish in Africa: A study on processing marketing and consumption. FAO Fisheries Tech. Paper. 1329.

Focardi S. Corsi I, FranchiE(2005) safety issues and sustainable mentally sound aquaculture: new tools for environmentally sound acquaculture. Aqualcul inter 13:317.

Ghay AE, Dave D, budge S, Brooks MS (2010). Fish spoilage mechanism and presentation techniques review. American journal of Applied science, 7(7), 2011, 1047-1051.

Gilmour A, McCallum MF, Allan MC. A study of the bacterial types occurring on the skin and in the intestine of farmed plaice(Pleuronectesplatessa L). Aquaculture 1976; 7:161-172.International Journal of foodMicrobiology, \&(2), 9-15.

Http:

//www.foa.org/fishery/countrysector/naomalaysia/en cited 5 November 2014.

Http://www.foa.org/docrep/003/v4430E/V4430 E00.htm.Cited 10Aughust 2012

Huisint-Veld, J.H(1996) Microbial and Biochemical spoilage of foods an overview.

Husseing, $K$ and Zolawdi, J. contribution of fisheries research to the improvement of livelihoods in west African fishing communities: Case study, Nigeria, (FAO and DFIO sustainable fisheries livelihoods programme, 2002).

Huss, H.H (1995). Quality and Quality changes in fresh fish. Rome: FAO Fisheries Technical paper.

Sumer, B.M (2014). Liquefaction Around Marine structures. Advanced series on ocean Engineering. Worlds scientific vol 39.

LUnestad BT, Nesse L. Lassen J, Svihus B, Nesbakken t, et al.(2007) salmonella in fish feed; occurrence and implication for fish 
and human health in Norway. Aquaculture 765:1-8

Martin, A.M (1994) fish processing: Biochemical Applications. Chapman and Hall, London.

W.H.O (2007). The worlds Health Report: Global public health security on the 21st century. Geneva, Switzerland.
Workagegn KB, Ababbo ED, TossaBT(2013) The effect of Dietary inclusion of Jatrophacurcas kernel meal on growth performance, feed Utilization efficiency and survival rate of Juvenite Nile tilapia J. Acquacul Res Develop. It:193. 